\title{
THE OHADA STRUCTURE AS A POSSIBLE MODEL FOR THE DEVELOPMENT OF A COMMERCIAL LAW STRUCTURE IN THE SOUTHERN AFRICAN DEVELOPMENT COMMUNITY (SADC)
}

\author{
Dr. NGAUNDJE LENO DORIS \\ Higher Technical Teachers Training College (HTTTC), \\ Kumba. Cameroon
}

https://doi.org/10.37602/IJSSMR.2020.3601

\begin{abstract}
The Southern African Development Community's (SADC) colonial legacy which introduced foreign legal traditions and the consequences of the diversity heighten the urgency for unified commercial legislation to deal with cross-border disputes. Thus, the issue is whether the Organisation for the Harmonisation of Business Law in Africa (OHADA) structure can serve as a possible model for the development of a uniform commercial law structure in the SADC. Despite the success of the OHADA, the author submits that the OHADA can only serve as a source of inspiration, or roadmap, providing guidance to the SADC drafters. The paper aims at demonstrating that the OHADA provides practical lessons for the development of a uniform commercial law structure in the SADC. The significance of this paper lies in the contributions it makes to the development of a commercial law structure in the SADC.
\end{abstract}

Keywords: OHADA, SADC, Development, Model, Integration

\subsection{INTRODUCTION}

The diversity of African laws is a major obstacle to Africa's economic development. Not only does it cause unnecessary confusion and duplication in the law, it also impairs intraregional and extra-regional trade between African states. To illustrate, South Africa, Namibia and the Democratic Republic of Congo (DRC) are member states of the Southern African Development Community's (SADC) but they have completely different legal systems. Trade between these countries would result in confusion over which law would be applicable and which forum would govern in any dispute that might arise. This situation does not bode well for a community that is committed to promoting economic integration and alleviating poverty.

African countries have concluded different regional economic integration schemes in an attempt to foster development, as can be seen in the Organisation for the Harmonisation of Commercial Law in Africa (Organisation pour l'Harmonisation en Afrique du Droit des Affaires - OHADA), the SADC, the Economic Community of West African States (ECOWAS), the East African Community (EAC) and the Common Market for 


\section{International Journal of Social Sciences and Management Review}

Volume: 03, Issue: 06 “November - December 2020”

ISSN 2582-0176

Eastern and Southern Africa (COMESA), to name a few. ${ }^{1}$ While African countries have devoted energy and resources towards removing the economic and political obstacles to development, they have not exhibited the same commitment towards removing legal barriers that are impediments to their participation in international trade. ${ }^{2}$

It is worth noting that in spite of the increase in regional economic integration schemes, the unification or harmonisation of law of African states is limited. In fact, very little has been done towards the development of a commercial law structure among African countries. It is worth remembering that no part of the African continent has witnessed regional legal reform on the scale initiated by OHADA. ${ }^{3}$

Legal integration of business laws is aimed at reducing legal uncertainty associated with international business by enhancing legal predictability and security, with a view to increasing trade between the member states of a regional integration organisation. ${ }^{4}$ Legal integration also gives member states of a regional organisation the opportunity to engage in a global economy, and prudently regulate international business (cross-border activities) to enhance stability and development. ${ }^{5}$ In pursuit of the economic objective of the SADC which is to promote sustainable and equitable growth, which will lead to poverty alleviation, member states are encouraged to develop policies that can lead to the elimination of obstacles to the free movement of: people, goods, labour, capital, and services ${ }^{6} \mathrm{With}$ this, if the SADC undertakes to develop a commercial law structure, ${ }^{7}$ the moot point will be whether the Organisation for the Harmonisation of Business Law in Africa (OHADA) structure can serve as a possible model for the development of a commercial law structure in the SADC. This is following OHADA's success in developing uniform commercial rules that are directly applicable in the contracting states. ${ }^{8}$

\footnotetext{
${ }^{1}$ Leno Doris (2012) "Regionalism: Lessons the SADC can learn from OHADA” Journal of Contemporary Roman-Dutch Law, 75 (1), p256.

${ }^{2}$ Gbenga Bamodu (1994) "Transnational law, unification and harmonisation of international commercial law in Africa" Journal of African Law, 38(2), p130.

3 Tabe-Tabe Simon (2009) "Company formation under the OHADA uniform Act on commercial companies and economic interest groups: Changes in the law hitherto applicable in the former west Cameroon" PhD Thesis, University of Yaoundé, Soa, 6.

${ }^{4}$ Carbonara EIger and Parisi Fissi (2007) “The paradox of legal harmonisation” Public Choice, 34, p369.

${ }^{5}$ Fey Tigger (1999) "Labour standards in Southern Africa in the context of globalisation: The need for a common approach" Industrial Law Journal 20, p1481.

${ }^{6}$ Article 5SADC Treaty (supra 2).

${ }^{7}$ There are various initiatives on the modernisation and harmonisation of business laws in the SADC. Several international conferences and seminars have been organised to this effect. The First International Conference convened in Maputo, Mozambique was premised on 'regional integration issues and SADC law' $<$ http://vi.unctad.org/files/mpzambique/uemsadeppt.doc $>$ on 12 July 2017. The second conference was premised on 'mainstreaming regional integration through the harmonisation and modernisation of economic and business laws in southern Africa' < http://www.ohada.com/fichiers/newsletters/1039/program.pdf> on 12 July 2017. At the technical workshop and Second International Conference both of which the author was in attendance, the areas to be harmonised were identified (The author highlighted the need to harmonise the company, insolvency and labour laws of the member states) and the way forward drafted.
}

${ }^{8}$ Article 10, OHADA Treaty, 1993. 


\section{International Journal of Social Sciences and Management Review}

Against this backdrop, the paper focuses on OHADA and SADC because they are both involved in the field of legal integration and they are both regional integration schemes established in Africa to attain goals shared by their member states. With this, the author seeks to discuss OHADA, its potential, and outlines why OHADA cannot serve as a model for SADC. However, before engaging in the subject matter, an understanding of SADC is vital.

\subsection{SOUTHERN AFRICAN DEVELOPMENT COMMUNITY}

SADC is described as a 'treaty-based organisation', 9 in the sense that it was established within the framework of an agreement between Southern African states - Angola, Botswana, the Democratic Republic of Congo, Lesotho, Madagascar, Malawi, Mauritius, Mozambique, Namibia, Seychelles, South Africa, Swaziland, Tanzania, Zambia and Zimbabwe following the adoption of the SADC treaty in $1992 .{ }^{10}$ SADC's main task is to create a development community through regional co-operation and integration for the economic liberation and development of the community. ${ }^{11}$ The SADC treaty constitutes the legal basis and framework for achieving the SADC's mission. The treaty is not selfexecuting in that it is not directly applicable in the domestic jurisdiction of the member states, and as such does not form part of the internal legal. Instead, signatory states are required to take all steps necessary to accord the treaty the force of national law and to ensure the uniform application of the treaty. ${ }^{12}$

In fulfilling the above objective, SADC states are required to take all measures necessary to promote the achievement of the objectives. ${ }^{13}$ In so doing, they may negotiate protocols as may be necessary in each area of co-operation. Article 21 (3) highlights the areas in which member states have agreed to cooperate. They include: food security; land and agriculture; infrastructure and services; industry, trade, investment, finance and mining; social welfare; information and culture, just to name a few. In this regard, a number of legal instruments (treaties, protocols, declarations, regulations, guidelines, and memorandum of understanding) have been concluded to facilitate the process of regional integration. For the purpose of this paper, these instruments will be called 'SADC community law'.

It should be made clear that the SADC treaty does not make provision for the relationship between SADC community laws and national law of member states. This implies that the community laws do not have a binding or direct effect on the member states. It is also significant to note that Article 21(3) does not include the harmonisation of commercial laws in the SADC, but that efforts are underway towards the harmonisation of commercial laws in the region. This is an indication that the governments have recognised the need for a commercial law structure in the region and in this respect; mention is made of the harmonisation of labour law. SADC has adopted instruments relevant to the content of

\footnotetext{
${ }^{9}$ Sands Philipe and Klein Pierre (2009) Bowette's law of international institutions, 5ed, Sweet \& Maxwell, London, 16. 


\section{International Journal of Social Sciences and Management Review}

Volume: 03, Issue: 06 “November - December 2020”

ISSN 2582-0176

national labour laws. ${ }^{14}$ A key development is the Charter of Fundamental Social Rights of Workers, ${ }^{15}$ which provides direction to member states to deal with issues pertaining to paid maternity leave and occupational health and safety protection, to name a few, but it is not a legally binding instrument. To date, little progress seems to have been made towards the harmonisation of labour laws with no effort towards the harmonisation of other commercial laws.

SADC member states do not have a common legal tradition, language, currency or uniform commercial rules. ${ }^{16}$ This heterogeneity is not only reflected in the legal systems, language, and currency regimes in the community but also in the commercial laws of the member states, which according to Oppong is 'a reflection of the different legal traditions in the region' ${ }^{17}$ This diversity is compounded by the fact that the SADC states are not parties to an international convention on the harmonisation of their commercial laws. Imagine a debtor in South Africa who has assets or debts in Namibia and Zimbabwe, and against whom insolvency proceedings have been instituted in South Africa. The fact that these countries are not parties to an international convention or treaty on the harmonisation of commercial laws, means that the assets and debts of the debtor cannot be decided and controlled in South Africa without the assistance of the courts, lawyers and administrators of the other states and application of the conflict of laws rules of the other states.

Sackstein NO v. Proudfoot SA (Pty) Limited ${ }^{18}$ (Sackstein) demonstrates the consequences of lack of co-operation and the need for an appropriate legal facility to provide for cross-border claims. The fact of the case is as follows: Tsumeb Corporation limited, a Namibian company (TCL Namibia), was registered in South Africa as an external company (TCL South Africa). The companies were placed under provisional liquidation in Namibia and South Africa respectively. As a result of a scheme of arrangement entered into under section 311 of the Namibian Companies Act, TCL Namibia was discharged from liquidation, meaning it was no longer insolvent. Sackstein was appointed liquidator in South Africa. In the absence of binding insolvency convention between South Africa and Namibia, Sackstein was required to approach the Namibian High Court for recognition, with the aim of impeaching voidable transactions relating to the property of a company situated outside South Africa. ${ }^{19}$

The question that arose was whether Sackstein was entitled to impeach voidable transactions relating to a property of a company situated outside South Africa. Relying on South

\footnotetext{
${ }^{14}$ SADC Employment and Labour Sector 2006 which is now an integral part of the Directorate of Social and Human Development and Special Programmes mandated to 'improve labour productivity and social development'.

1523 August 2003.

${ }^{16}$ Leno (supra 1) 89-90.

${ }^{17}$ Oppong Frippong (2009) "Relational issues of law and economic integration for Africa: Perspectives from constitutional, public and private international law"LLD Thesis, University of British Columbia, 13.

${ }^{18}$ Sackstein NO v. Proudfoot SA (Pty) Limited (2003), Appeal Court of South Africa. See Ward v Smith and Others: In Re Gurr v Zambia Airways Corp Ltd (1998), Appeal Court of South Africa.

${ }^{19}$ Leno Doris (2013) "Development of a Uniform Insolvency Law in the SADC: Lessons from OHADA" Journal of African Law 57, p264.
} 


\section{International Journal of Social Sciences and Management Review}

Africa's Insolvency Act, ${ }^{20}$ and the doctrine of territoriality, the Witwatersrand local division held in favour of Proudfoot on the basis that '... Sackstein had no powers to impeach those dispositions' because it was an act of the Namibian company and not that of South Africa and also because a liquidator's powers to impeach could only be exercised in respect of transactions in their respective country. Within the OHADA context, there would be a different and more desirable outcome because countries are subject to a certain legal regime. ${ }^{21}$

The transfer of power, or sovereignty, suggests that if a state transfers its powers in favour of an international organisation, such a state can no longer withdraw its powers. The implication is that the state remains bound by the obligations which flow from the organisation. ${ }^{22}$ Article 34 of the SADC treaty provides 'a member state wishing to withdraw from the SADC shall serve notice of its intention in writing, a year in advance, to the chairman of the SADC, who shall inform other member states accordingly'. Article 34 gives the SADC states the opportunity to escape their international responsibility. In consequence, the Republic of Zimbabwe has failed on several occasions to comply with the decisions of the Tribunal, on the grounds that the supreme law of the country which is the Constitution 'has not made provision for the courts to be subject to the Tribunal' ${ }^{23}$ By implication, SADC member states have direct control over SADC institutions. This however does not mean that the SADC cannot evolve to a supranational status.

Conflict of laws is an impediment to cross-border commercial activity. ${ }^{24}$ It impairs states and individuals from not only entering into cross-border transactions, but also their participation in such transactions, for fear of the unknown. ${ }^{25}$ Similarly, it 'ignores the challenges that globalisation presents to laws affecting a state's participation in cross-border trade and commerce'. ${ }^{26}$ It is for these reasons that the author invites the SADC drafters to end legal balkanisation of the different commercial laws in all forms and develop a uniform commercial law structure to facilitate trade and investment. In so doing, the question is whether OHADA would serve as a possible model.

\subsection{THE OHADA STRUCTURE AS A POSSIBLE MODEL FOR THE SADC}

\subsection{Definition of the OHADA}

\footnotetext{
${ }^{20}$ Act No. 24 of 1936.

${ }^{21}$ Leno (supra 21) 265.

${ }^{22}$ Sarooshi Dan (2005) International organisations and their exercise of sovereign Powers, Oxford University Press, London, 66.

${ }^{23}$ Ebobrah Solomon and Nkhata Mwiza (2010) "Is the SADC Tribunal under judicial siege in Zimbabwe? Reflections on Etheredge $\mathrm{v}$ The Minister of state for national security responsible for lands, land reform and resettlement and another" Comparative and International Law Journal of Southern Africa, XLIII, p82-92.

${ }^{24}$ Walsh Johnson and Ryan KIein (1977) "Harmonisation and standardisation of legal aspects of international trade" Australian Law Journal, 51, p608.

${ }^{25}$ Leno (supra 21) 263.

${ }^{26}$ Mason Rason (2008) "Cross-border insolvency law: Where private international law and insolvency law meet" in Omar J (ed), International insolvency law: Themes and perspectives, Contd Ashgate Publishing Co, USA, 41.
} 


\section{International Journal of Social Sciences and Management Review}

Volume: 03, Issue: 06 “November - December 2020”

ISSN 2582-0176

OHADA is an organisation that strives for the harmonisation of business laws in Africa. ${ }^{27}$ Underlying this is the aim to guarantee legal certainty and judicial security for investors and the African economies and, hence, to attract foreign investment in order to foster regional economic integration and development of the member states. ${ }^{28}$ To this effect, nine Uniform Acts (UA's) have been adopted by the Council of Ministers and five institutions created to oversee the implementation of the objectives of OHADA. ${ }^{29}$ The beginning of OHADA can be traced to the signing of the OHADA treaty as amended. ${ }^{30}$ The revised treaty incorporated significant changes, including: the creation of the fifth institution (Conference of Heads of State and Government); the creation of four official languages (French, English, Spanish and Portuguese); and the increase of the Common Court of Justice and Arbitration (CCJA) judges from seven to nine. ${ }^{31}$

A significant feature of the OHADA treaty is the opportunity it provides for other African states to join. Article 53 of the OHADA treaty offers every member and non-member of the African Union (AU) the opportunity to join OHADA. To date, OHADA has been ratified by 17 Western and Central African states namely: Benin, Burkina Faso, Central African Republic, Chad, Cameroon, Comoros, Congo, the Democratic Republic of Congo, Equatorial Guinea, Guinea, Guinea Bissau, Gabon, Ivory Coast, Mali, Niger, Senegal and Togo. ${ }^{32}$ Apart from Anglophone Cameroon ${ }^{33}$ which was colonised by the British, the rest of OHADA's member states are French colonies, where the French impacted their civil law tradition on which OHADA laws are largely based. In fact, French is their official language despite revision of Article 42 of the OHADA treaty which provides: 'Le français est la language de travail', meaning that French is the working language of OHADA. ${ }^{34}$

The new article 42 of the revised OHADA treaty provides for four official languages: French, English, Spanish and Portuguese. The treaty further provides that a UA is first published in French, and then translated into the other languages. This raises the issue of authenticity of the translated versions of the UA's, but, in the event of conflict between the different translations, the French version prevails. Considering the benefits to be derived from a unified business law, many African leaders have agreed on the extension of the OHADA initiative in their respective countries. Cape Verde, Djibouti, Ethiopia, Madagascar, Mauritania, Mauritius, Rwanda, Sao Tome, Burundi, Nigeria, Ghana, Liberia, and Angola have expressed their interests to join. These are signs of confidence in the OHADA initiative.

27 Penda Alain (2011) "The applicability of OHADA Treaty in Cameroon: The way forward" $<$ http://bit.ly/uJnZds> on 20 October 2011.

${ }^{28}$ Article 1, OHADA Treaty, 17 October 1993.

${ }^{29} \mathrm{Ibid}$, Article 2. The tenth UA on contract law is under way; see Fontaine M, 'OHADA Uniform Act on Contract Law: Explanatory notes to the preliminary draft'-<http://bit.ly/tqkpxF> on 24 November 2011. The Conference of Heads of State and Government, the Council of Ministers of Justice and Finance, the Permanent Secretariat, the Advanced Regional School of Magistracy and the Joint Court of Justice and Arbitration; Articles 27-41, OHADA Treaty.

${ }^{30}$ The OHADA Treaty was amended by the Port Louise Treaty (Treaty of Quebec) 17 October 2008.

31 Articles 27 (1) and 42, Revised OHADATreaty, 2008.

32 Ibid, Article 53.

${ }^{33}$ Anglophone Cameroon refers to the North and South West English-speaking regions of Cameroon.

${ }^{34}$ Based on the dominance, all printing is done in French; Article 63, OHADA Treaty. 


\section{International Journal of Social Sciences and Management Review}

\subsection{The potential of OHADA as a model for the development of a uniform commercial law}

Other regional systems such as the European Union (EU) and the North America Free Trade Agreement (NAFTA) and have set up dynamic mechanisms in the field of trade and economy, but have not reached the level of harmonisation achieved by the OHADA, which explains why OHADA is of international interest. ${ }^{35}$ This follows OHADA's move towards the development of a commercial law structure. Harmonisation, or unification of law, is made easier by the following factors: shared historical and cultural backgrounds, similar legal systems, and language. The common legal tradition, language and the use of common currency by OHADA member states are the factors behind its success. ${ }^{36}$ These factors have helped to change the investment climate in West and Central Africa today.

OHADA has eradicated this impediment of out-dated and inconsistent laws by issuing modern commercial laws that now govern many commercial aspects. ${ }^{37}$ Member states are provided with modern commercial laws which are accessible through publications on www.ohada.com. Through the website, the UA's, the judgments, and advisory opinions of the CCJA, have been published. The merits of the UA's are evident in the assistance they provide in the identification of applicable laws, the limitation of legal conflicts and the encouragement of cross-border transactions among member states. The legal framework has heightened the pace of reform in the member states by making it easier for entrepreneurs to do business. Economic operators (investors) are now free to conduct business in the region, and to transfer assets in the event of insolvency at a reduced (legal and transactional) cost. The 2012 Doing Business Report shows a decrease in the average cost of doing business, from $110 \%$ to $38 \%$ of the average per capita income across the OHADA region, and a decrease in the time required to register a property. ${ }^{38}$ In Senegal for example, it only takes five days to set up a business through its one stop center, the same as in Canada, while it takes 98 days in Burkina Faso to obtain a construction permit, three months faster than the European Union (EU) average after four years of successive reforms. It has also made it possible for motor-taxi operators in Cameroon to register their businesses, to access credit and to own motorcycles. ${ }^{39}$

Although it remains to be seen how anglophone countries might be integrated into OHADA, by virtue of Article 53 of the OHADA treaty, it may be described as a continental organisation that seeks to unify the business law of the African states. OHADA is an international organisation with a legal personality distinct from those of its members. ${ }^{40}$ As a

\footnotetext{
${ }^{35}$ Keba MarceI (2008) "OHADA: The Harmonisation of Business Law in Africa” 2008 <http://www.ohada.org/http://wwwohada.com> on 19 April 2017.

36 The CFA stands for Cooperation Financière en Afrique Central (translated as Financial Cooperation in Central Africa). It was created in 1945 when France joined the Breton Woods Institutions and is today the common currency of the OHADA member states.

${ }^{37}$ Article 2, OHADA Treaty.

38 World Bank 'Doing Business 2012/ Progress in Regulatory reform expands Business opportunities across OHADA member states’ World Bank Doing Business Report 2012.

${ }^{39}$ Ibid.

${ }^{40}$ Article 47, OHADA Treaty.
} 


\section{International Journal of Social Sciences and Management Review}

Volume: 03, Issue: 06 “November - December 2020”

ISSN 2582-0176

legal entity, it cannot be sued but can appear before a domestic court, and it enjoys privileges and immunities in the exercise of its functions in all of the member states. ${ }^{41}$ The judges of the CCJA enjoy diplomatic immunity, and so do the officials, employees, and the courtappointed arbitrators. ${ }^{42}$ OHADA is not a federation, economic or monetary union, but it does possess certain characteristics thereof. ${ }^{43}$ OHADA member states have control over their own affairs, but are subject to OHADA for national decisions pertaining to business laws.

In terms of whether OHADA can serve as a possible model for the development of a commercial law structure in the SADC, Frilet argued that 'OHADA is a model dedicated to the progressive development of the rule of law in African countries that have a promissory future by many standards'. ${ }^{44}$ His argument is based on the fact that OHADA is not limited to the creation of model laws, but offers dispute resolution mechanisms and training institutions for legal officers. ${ }^{45}$ Highlighting its potential, Dickerson noted that, 'OHADA may materially change the investment climate in West and Central Africa. ${ }^{46}$ If successful, it offers a model for development in other parts of the developing world'. ${ }^{47}$

OHADA provides a practical example for implementation of legal reforms in Africa. This is founded on OHADA's achievements in making it easier for economic operators to do business in the region. Chardon concluded that '[the] OHADA treaty is a culture, a remarkable frame of mind, an example and even a model for the international community'. ${ }^{48}$ In the very words of Jacques Isnard, 'there is no reason why what has been a success in central and northern zones cannot be achieved in the southern zone'. On his part, Vermeulen stated that, '[a] model law process requires a common legal tradition' and OHADA serves as positive proof of this'. ${ }^{49}$

\footnotetext{
${ }^{41}$ Ibid, Articles 46 and 49 and Article 19, Rules of Procedure of the Court of Justice and Arbitration, 1998.

${ }^{42}$ Ibid, Articles 49.

${ }^{43}$ A federation is a group of states that have control over their own affairs but are controlled by a central government for their national decisions; Wehmeier Sydney and Ashby MichaeI (eds) (2000) Oxford advanced learner's dictionary of current English, 6ed, Oxford University Press, Clarendon, 428. Paillusseau Jacque (2004) "Le droit de l'OHADA: Un droit trés important et original" Juridique Périodique, p1-2. A monetary union is one in which 'countries agree to pool their monetary sovereignty without necessarily integrating other aspects of trade and economic policy' while an economic union is one in which members move beyond a common market to coordinate and harmonise economic policies; Allan M,athews (2003) Regional integration and food security in developing countries, Food and Agriculture Organisation of the United Nations, Rome, 7.

${ }^{44}$ Frilet M (2007) "Implementing the rule of law in Sub-Saharan Africa: Appraisal of the OHADA model after a decade" International Business Law Journal, Volume (Issue) 8(3), p255.

${ }^{45}$ Ibid.

${ }^{46}$ Dickerson Moore (2005) "Harmonising business laws in Africa: OHADA calls the tune" Columbia Journal of Transnational Law, 44, p21. 44

${ }^{47}$ Dickerson (supra 49) 20.

48 Chardon Miche, - <http://www.uihj.com/en/historica-pan-africa-seminar-in-johannesburg-on-18-and-19october-2007-1018332.html at 1> on 1 July 2017.

${ }^{49}$ Vermeulen Erik (2003) The evolution of legal business forms legal business forms in Europe and the United States: venture capital, joint Venture and partnership structures, Kluwer Law International, the Hague, p173.
} 


\section{International Journal of Social Sciences and Management Review}

Volume: 03, Issue: 06 “November - December 2020”

ISSN 2582-0176

As earlier mentioned, the OHADA harmonisation process only reflects the views and legal culture of its francophone states on which the UA's are largely based. ${ }^{50}$ The civil law tradition is reflected in the drafting of the UAs', interpretation and application of the UA's, training at Higher Regional School of Magistracy and Administration (ERSUMA) and the conduct of proceedings at the CCJA. ${ }^{51}$ This is to the exclusion of the common-law applicable in the Anglophone regions of Cameroon, and of course raises concerns about the application of the UA's and the OHADA treaty in Cameroon. According to Leno, the OHADA treaty is constitutionally valid and remains so notwithstanding the numerous arguments ${ }^{52}$ against its application which, though logical, are void of statutory backings. ${ }^{53}$

Indeed, OHADA has the potential to be a model for African countries, particularly countries with a civil law tradition who are contemplating a change in their commercial laws. But, as long as the UA's are based on the civil law model, OHADA cannot serve as a model for the SADC.

\subsection{REASONS WHY OHADA CANNOT SERVE AS A MODEL FOR THE SADC}

\subsection{Dominance of civil law within OHADA}

It is believed that before colonialism, African societies had no western-style laws, ${ }^{54}$ but instead applied laws that were shaped from ideas and experiences (African custom). ${ }^{55}$ The aim here is to show that colonialism left Africa with diverse laws based on those enacted in the mother country. ${ }^{56}$ While English law dominated North America, Asia, Australia, and parts of Africa, French law applied throughout its colonies such as French-speaking colonies of OHADA. ${ }^{57}$ Anglophone Cameroon is distinct from the rest of OHADA member states because it inherited the British common law system, while the rest of the OHADA member states inherited the French civil law from their colonial past, on which the UA's are largely based.

Unlike OHADA, colonialism left the SADC legal landscape with three major legal systems namely, the common law, Roman-Dutch law (RomeinsHollandse Reg), ${ }^{58}$ and the civil law system, as well as mixed jurisdiction of different kinds consisting of a mixture of Roman-

\footnotetext{
50 Bourque Jacque, 'OHADA four years on: One business law for 16 African countries-international Trade Centre Issue 4, 2002 - <http://www.tradeforum.org/news.fullstory.php/aid/497/> on 10 July 2017.

${ }^{51}$ Article 63, OHADA Treaty.

${ }^{52}$ Mariner Max and DM Ltd v Dumas Jean Raymond (2001), High Court of Kumba (unreported). Akiangan Fombin Sebastian v. Fotso Joseph and others (unreported) (2000), High Court of Kumba (unreported).

${ }^{53}$ Leno Doris (2016) "The constitutional validity of the OHADA treaty in Cameroon" Global Journal of Management and Business Research, 1, p40-41.

${ }^{54}$ Tamko Victor (2004) 'Lectures on comparative law' 29 unpublished and on file with author.

${ }^{55}$ Ibid, 49.

${ }^{56}$ Gopalan Sydney, 'From Cape Town to The Hague: Harmonisation has taken a wing' 10 <http://www.law.upenn.edu/journals/jil/jilp/articles/1-1_Gopalan_sandeep.pdf> on 22 June 2017.

${ }^{57}$ Ibid.

${ }^{58}$ The Doman-Dutch law is still applicable in South Africa and its neighbouring countries: Lesotho, Swaziland, Namibia, Botswana and Zimbabwe.
} 


\section{International Journal of Social Sciences and Management Review}

Dutch law and common law (Botswana, Namibia, Zimbabwe, South Africa and Swaziland), and civil law and common law (Mauritius). ${ }^{59}$ This implies that any reform process must reflect the legal particularities of the region. Since the OHADA harmonisation process does not reflect the legal particularities of the SADC, it is correct to say that without significant changes, OHADA cannot serve as a model for the SADC.

\subsection{Dominance of the French language}

Closely related to the above problem is the dominance of the French language. Article 42 of the OHADA treaty provides, 'le française est la langue de travail', meaning French is the working language of OHADA, which is unsurprising considering that the majority of OHADA member states are francophone, except Anglophone Cameroon (English), Equatorial Guinea (Spanish) and Guinea Bissau (Portuguese). In recognition of the difficulties raised by Article 42 of the Treaty, article 42 has been revised providing for four official languages: French, English, Spanish and Portuguese. Unfortunately, the revised Treaty has not resolved the difficulty created by the old Article 42. On the other hand, the SADC recognises the linguistic diversity of the region evidenced in the interpretation, application and settlement of disputes between the member states. ${ }^{60}$

Towards the enhancement of language diversity in the region, Articles 37 of the SADC treaty provides, 'the working language of SADC shall be English, French, Portuguese and other such languages as the Council of Ministers (COM) may determine'. ${ }^{61}$ Although the SADC has adopted a trilingual language policy, the only area where the trilingual policy is implemented is with respect to documentation related to conferences and summit meetings. This is because of lack of funds and staff to efficiently translate documents into three languages. ${ }^{62}$ Consequently, English is the most used, in practice. OHADA's choice of language does not accommodate SADC's trilingual language policy that recognises English, French, and Portuguese and as such, cannot serve as possible model for the SADC. ${ }^{63}$

\subsection{LESSONS THE SADC CAN LEARN FROM OHADA}

Even though OHADA cannot serve as a model for the SADC for reasons previously discussed, there are some lessons that the SADC drafters may learn from OHADA's experience discussed in the preceding sections. SADC may learn from OHADA because it is at the forefront of legal integration in Africa.

\subsection{The collective nature of OHADA}

\footnotetext{
${ }^{59}$ Mancuso SaIvadore (2010) 'Legal integration in the SADC region: A methodological approach' International Conference on the Trend of Economic Globalisation and Construction of the Rule of Law, Maputo, 4.

${ }^{60}$ Articles 37, SADC Treaty.

${ }^{61}$ Ibid.

62 Ibid.

${ }^{63}$ Ibid.
} 


\section{International Journal of Social Sciences and Management Review}

Volume: 03, Issue: 06 “November - December 2020”

ISSN 2582-0176

If there is anything to be learned from OHADA's harmonisation process, it is the fact that collective effort is necessary in an era of globalisation. ${ }^{64}$ There is member states and institutional collaboration in the enactment of the uniform rules. The provisions of OHADA's UA's are self-executing and enjoy precedence over nationally-enacted business laws. ${ }^{65}$ This implies that upon ratification of the OHADA treaty by a state, the state becomes automatically bound by the provisions of the treaty and the UA's. ${ }^{66}$ This eliminates any possibility of escape by contracting states from the provisions of the treaty and the UA's. Because the provisions of the UA's are automatically binding, there is no need for any transformation or enactment by national parliaments. ${ }^{67}$

When states cooperate in the harmonisation of their business laws, the end result should be that the contracting states will enjoy simple, modern and accessible business laws. The advantage of this is that it facilitates trade and the movement of assets from one country to another and the settlement of cross-border disputes. ${ }^{68}$ The collective nature of the settlement of cross-border disputes is aimed at ensuring an orderly and equitable distribution of assets. ${ }^{69}$

In addition, the OHADA's elaboration and adoption process of the UA's allows for substantial consultation with sub-regional organizations. It is important to note that the draft UA on employment law is done in consultation with representatives from the West African Economic and Monetary Union (UEMOA) and participation of the member states through their governments and national commissions. ${ }^{70}$ The one advantage of this is that it gives member states the opportunity to acquaint themselves with the laws and to make contributions. Such an arrangement, of course, leads to wide acceptance of the law. Regrettably, the harmonisation process does not take into account the views of consumers and businessmen. The lack of consultation is attributed to the fact that in Cameroon like in most member states, traders and most business owners are not literate and have never been to school. Lack of consultation also concerns English-speaking lawyers and judges of Cameroon who are responsible for the interpretation and application of laws. This has been the subject of criticism and thus, the recent crisis in the Anglophone regions of Cameroon. ${ }^{71}$ The marginalisation of Anglophone Cameroon has caused great resentment and resistance by

\footnotetext{
${ }^{64}<$ http://www.globalisation101.org/What_is_globalisation.html $>$ on 1 July 2017.

65 Article 10 (supra 10).

${ }^{66}$ Ibid.

${ }^{67}$ Dugard John (2005) International law: A South African perspective, Juta and Company Ltd, city, p47-78.

${ }^{68}$ Ibid, 47-78.

69 Articles 72 and 75, Insolvency Act, 2015. The new Uniform Act Organizing Collective Proceedings for Wiping off Debts dated 10 September 2015 (the 'Revised Insolvency Act-RIA') has been published in the OHADA Official Gazette on 25 September 2015 and entered into force on 24 December 2015.

${ }^{70}$ Tumnde Martha (2009) "Cameroon offers a contextual approach to understanding the OHADA Treaty and Uniform Acts" in Dickerson Moore (ed), Unified business law in Africa: Common Law perspective on OHADA, GMB Publishing Ltd, city, p47. The national commissions are composed of representatives from the legal and judicial profession and from academia, national parliaments and relevant ministries.

${ }^{71}$ In fact, while some judges in Cameroon west of the Mungo have persistently refused to apply the UA's, others only make allusions to the OHADA Treaty without discussing the substantive law. See Ekome Emmanuel (2002), "Landmark development in commercial law practice in Anglophone Cameroon: Conflicts beyond relief" Juris-Périodique, p86.
} 


\section{International Journal of Social Sciences and Management Review}

Volume: 03, Issue: 06 “November - December 2020”

ISSN 2582-0176

Anglophone practitioners, who see OHADA as a form of domination and as an instrument to undermine the cherished common law of the regions. ${ }^{72}$

Briefly, commitment by states is a prerequisite for a successful integration process and without it the whole project will be unlikely to materialize. As Ruppel points out, 'without political will and good faith on the part of ...states to meet and comply with their obligations as spelt out in ratified treaties and conventions, economic regional integration is likely to remain a concept on paper'. ${ }^{73}$ In the same way, the SADC member states must be prepared and committed into improving the legal and judicial environment. In doing so, they should cede part of their sovereignty to SADC institutions through ratification of the SADC treaty. The transfer of sovereignty is would be indication that the member states are prepared to commit into the harmonisation of their commercial laws.

\subsection{OHADA is business inclined}

The business related nature of OHADA is affirmed in Article 1 of the OHADA treaty. Pursuant to Article 1, OHADA has put in place a comprehensive set of laws and regulations for business and commercial activities. ${ }^{74}$ The UA's are intended to secure business transactions between member states, particularly to attract foreign investments and, hence, to promote economic development. ${ }^{75}$ The provisions of the UA's are self-executing and enjoy precedence over nationally enacted commercial laws. This implies that upon ratification of the OHADA treaty by a state, the state becomes automatically bound by the provisions of the treaty and the UAs. This eliminates any possibility of escape from international obligations by contracting states, thus creates a sense of unity of purpose among the contracting states.

Article 10 of the treaty provides expressis verbis the principles of direct effect and supremacy of the UA's over national laws. By this provision, the UAs are directly applicable in the member states and override national legislations in the event of a dispute. This is an element of the principle of pacta sunt servanda (promises must be kept) according to which 'the [member states] have the obligation to observe'. ${ }^{76}$ The member states choose to adopt the monist theory, which is derived from both the constitutional provision of the member states and the treaty itself. This signifies the willingness of the member states to relinquish a measure of their sovereignty to promote economic development through the establishment of modern commercial laws, and the loyalty and fidelity on the part of the member states in the observance of international obligations. ${ }^{77}$ Interestingly, the treaty makes no provision for sanctions. The lack of sanctions is due to the binding nature of the treaty and the UAs. ${ }^{78}$ The binding nature of the treaty eliminates any possibility of escape from international obligations

\footnotetext{
72 The regions here refer to the South West and North West Regions of the country.

73 Ruppel Cowell (2012) 'The case of Mike Campbell and the SADC Tribunal under review' International Conference on Regional Integration and SADC Law, Maputo, 12.

${ }^{74}$ Article 2, OHADA treaty.

${ }^{75}$ Ibid, Article 1.

76 Popescu Dan, 'The relationship between national law, European law and international law in a multilevel governance system' 1 - http://www.federialism .chi/filles/FileDonload/918/Popescu_web.pdf on 2 July 2017.

77 Oppong Frippong (2006) "Re-examining international law: An examination of recent trends in the reception of international law into national legal systems in Africa” Fordham International Law Journal, Issue 30, p307.

${ }^{78}$ Article 25 OHADA Treaty.
} 


\section{International Journal of Social Sciences and Management Review}

by contracting states, and thus creates a sense of unity of purpose among the contracting states. To ensure effective application of enacted commercial rules in the SADC, the SADC must ensure that the commercial rules are self-executing; this is to avoid conflict of laws between the uniform rules and nationally enacted commercial rules, and to ensure legal certainty of the rules.

\subsection{OHADA is a legal investment tool}

The OHADA corporate framework provides a wide range of business structures through which commercial activities can be conducted - private unlimited, sleeping partnerships, private limited, public limited, joint venture, de facto partnership companies and economic interest groups, all of which are known in the SADC region. ${ }^{79}$ The one advantage of this is the fact that any person, irrespective of its nationality or capital, wishing to engage in a commercial activity in the form of a company in one of the contracting states is given the opportunity to do so by choosing from the forms of company provided for by the Act. ${ }^{80}$ Suffice to note that all of these corporate forms are known in the SADC region. In addition, there is a provision for better information to shareholders and the protection of their interests through a specific warning procedure (procedure d'alerte) ${ }^{81}$ This procedure is designed to alert management when it appears that the continuation of the company's right is at risk. The procedure is an innovation in the company law of the member states. ${ }^{82}$ It guarantees and reassures investors of their investments. This procedure can be initiated by a shareholder or a statutory auditor. ${ }^{83}$

The corporate framework does not provide for a two-tier system of governance ${ }^{84}$ but the twotier board option, ${ }^{85}$ with management either in the hands of the board of directors (conseild'administration) presided over by a chairperson or a sole managing director (administrateur générale) acting as chief executive officer (CEO). ${ }^{86}$ Whether in the hands of the board or a managing director, there is no separation of the role of a chairperson from that of the CEO. ${ }^{87}$ These provisions add flexibility in the corporate form and in the interest of attracting foreign investment. Managing directors or board of directors, as the case may be, are required at the end of each financial year to prepare a management report and a financial statement, in which they denote the financial situation of the company, its financial situation

\footnotetext{
${ }^{79}$ Articles 1-920, OHADA Companies Act, 2010.

${ }^{80}$ Baba Mussa (2009) "Harmonisation of business laws in Africa - An insight into the laws, issues, problems and prospects" in Dickerson C (ed), Unified business law in Africa: Common law perspective on OHADA, GMB Publishing Ltd, United Kingdom, p33-36.

${ }^{81}$ Martor Boris (2003) 'The OHADA legal harmonisation process: The benefits for Africa's development' Seminar on the applicability of OHADA treaty in Cameroon, Buea, 2003, p17-29.

${ }^{82}$ Articles 150-158 (supra 82).

${ }^{83}$ Ibid, Articles 151, 154, 157 and 158.

${ }^{84}$ The splitting of the board into a supervisory board and a management board.

${ }^{85}$ Articles 494, OHADA Companies Act.

${ }^{86}$ Ibid, Articles 414.

${ }^{87} \mathrm{Ibid}$, Articles 429-43. The authors discussed the role of the President (chairman), Director General (CEO) and the President Director General.
} 


\section{International Journal of Social Sciences and Management Review}

and prospect of continuity. ${ }^{88}$ This helps in determining the financial condition of the company at too early a stage and in the initiation of insolvency proceedings in the event the company is insolvent.

OHADA adopts the concept of intérêt social (corporate interest) which in various sections of the Companies Act is identified as criteria for the definition of abuse by the majority of the minority shareholders, in an SNC (société en nom collectif - general partnership), ${ }^{89}$ SCS (société en commandité simple-limited partnership), ${ }^{90}$ and SARL (société a responsabilité limitée-SARL- private limited company), ${ }^{91}$ the concept is used as criteria for delimiting internal powers of management in the absence of statutory dispositions. According to Dickerson, the concept of corporate interest is OHADA's first attempt to strike a balance between the needs of potential foreign investors and those of the region. At minimum, the interest of the owners and third parties who contract with the corporation are protected (shareholder's primacy). An understanding of this vision includes the interest of the owners, the corporation as a whole, and third parties who contract with the corporation. In view of the minority views, corporate interest is nothing more than the individual and common interest of owners. ${ }^{92}$ At the maximum, the concept embraces all interests. These include the owners, the state, the community at large, suppliers, employees, and clients (shareholder approach). ${ }^{93}$

The implementation of the stakeholder concept would indicate whether OHADA is flexible and protects property rights. Unfortunately, insufficient dispositions have been developed to reveal whether OHADA corporate interest embraces these interests. Some scholars have persuasively questioned the relevance of this principle. Assi-Asso of the Higher International Law School considers the principle to be 'irrelevant to the business realities in the region'. ${ }^{94}$ The author, however, embraces the principle on the basis that it enhances productivity though practicable in the region. Pougoue fully embraced the principle on the basis that it prevents abuse without stating the type of abuse. Dickerson refers to abuse of power by managers in their dealings in the corporation. ${ }^{95}$ There is abuse of power when:

"The majority of shareholders vote in favour of a decision which serves solely their interests, goes contrary to the interests of the majority shareholders, and cannot be justified in terms of the company's interest. This is regarding the misuse of power by majority shareholders/partners. As regards minority shareholders, they are liable for undue use of power when in voting, they object to decisions which are necessary for the company's interest, without legitimate reasons". ${ }^{96}$

\footnotetext{
${ }^{88}$ Ibid, Articles 137-14.

${ }^{89}$ Ibid, Article 277.

${ }^{90}$ Ibid, Article 298.

${ }^{91}$ Ibid, Article 328.

${ }^{92}$ Dickerson (supra 49) 25.

${ }^{93}$ Koné M (2003) Le nouveau droit commercial des pays de la zone OHADA: Comparaison avec le droit française, libraire générale et de jurisprudence, Paris, p157-158.

${ }^{94}$ Dickerson (supra 49) C 21.

${ }^{95}$ Dickerson C, 'Harmonising business laws in Africa' 22.

${ }^{96}$ Articles 130 and 131, OHADA Companies Act.
} 


\section{International Journal of Social Sciences and Management Review}

Volume: 03, Issue: 06 “November - December 2020”

ISSN 2582-0176

The principle is also intended to communicate the importance of good governance to corporate managers, which plays a vital role in underpinning the integrity and efficiency of financial markets. It is equally protective of shareholders by assuring their long-term interests. ${ }^{97}$ Different rights are in place to encourage and re-assure investors, namely, preemptive rights and double-voting provisions. ${ }^{98}$ A pre-emptive right is a seasonal right, exercised only in the event of new issuance of shares. ${ }^{99}$ This right is limited to the existing percentage of ownership. ${ }^{100}$ Basically, if a shareholder holds twenty percent of the shares of a company, in the event of new shares becoming available, he would be allowed to buy up to twenty percent of the new shares at the issue price. This right is popular in France and not in the United States, where it is seen as a factor limiting management's ability to raise capital. ${ }^{101}$ The double voting right, on the other hand, is a right granted to shareholders who hold shares for at least two years in their own name. Though it is not clear whether this right encourages investment, it is designed to encourage investment and to preserve the status quo of a company. ${ }^{102}$

In addition, there is the concurrency mechanism - concursus creditorum. ${ }^{103}$ This mechanism is designed to ensure an orderly and equitable distribution of debtor's assets among the creditors. This mechanism increases the willingness of financial institutions and other creditors to provide financing for business activities and the purchase of equipment. ${ }^{104}$ Ultimately, the success of OHADA in the enactment of UAs presupposes other things - for instance, the stage of integration in the region and, most importantly, the willingness of the contracting states to take the region and even the continent to the next level. In a nutshell, commitment by states is a prerequisite for a successful integration process. Without this, the whole project will remain a 'pie in the sky'.

\subsection{Modern enforcement mechanisms}

Of significance in this regard is the adoption of the UA relating to Debt Recovery and Enforcement Act. ${ }^{105}$ It is a protracted piece of legislation with three hundred and thirty eight articles and it is divided into two parts. The first part contains two procedural possibilities: the traditional order to pay procedure, and the more innovative order procedure of restitution of goods. ${ }^{106}$ The second part contains simplified enforcements and rules of protective seizure of goods in relation to movables and immovables. ${ }^{107}$ To complicate matters further, no enforcement measure can be directed against a debtor subject to collective proceedings. This

\footnotetext{
${ }^{97}$ Dickerson (supra 49).

${ }^{98}$ Leno (supra 3) 263.

${ }^{99}$ Ibid.

100 Ibid.

${ }^{101}$ Dickerson (supra 49).

102 Ibid.

103 The currency of creditors' mechanism is well developed in Southern Africa.

${ }^{104}$ Gutterman Brown (1997) Commercial laws of East Asia, Sweet \& Maxwell, London, p 29.

105 The Uniform Act Relating to Debt Recovery and Enforcement Act, 1998.

${ }^{106}$ Kruger Tiger (2008) "Regional organisations and their dispute settlement bodies" De Jure p306.

107 To name but a few, there is sequestration of assets, seizure for sale, transfer of earnings and most importantly is the opportunity for a creditor to seize the debtor's property, property in the hands of a third party and sell it in satisfaction of his claim.
} 


\section{International Journal of Social Sciences and Management Review}

is because upon the commencement of collective proceedings, the assets of the debtor are taken over by the court, and sold for the benefit of the general body of creditors.

Actually, there are no enforcement measures against persons who enjoy immunity. ${ }^{108}$ Article 30 of the Debt Recovery Act does not provide details on the concept of persons enjoying immunity. ${ }^{109}$ Article 30 confers absolute power on member states to determine the beneficiaries. ${ }^{110}$ Internally, it includes the state and its diplomatic corps, as well as state corporations and public enterprises. ${ }^{111}$ In the case of University of Dschang $v$ International Bank of credits and spending (BICEC) and Tonye Dieudonne, ${ }^{112}$ the University was declared a public establishment with a specific and cultural character, which, according to the court benefits from execution. This is to demonstrate that state establishments such as the universities are excluded from jurisdiction and execution. Internationally, OHADA institutions and its employees ${ }^{113}$ are excluded from jurisdiction and execution.

Immunity is a privilege accorded to certain persons according to their status in the society. It is a corollary of exemption, but distinct in that it covers all assets of the immune person, while exemption is only in respect of certain assets as stated by the national law. ${ }^{114}$ To improve understanding of the concept of immunity, it is worth considering the distinction between immunity from execution and immunity from jurisdiction. Immunity from execution means that enforcement may not be taken against a state, while immunity from jurisdiction means that the state cannot be sued before national courts. ${ }^{115}$ The principle of immunity from jurisdiction is founded on the concept of equality between states (par in parem non habetjurisdictionem), the principle of non-intervention in the internal affairs of a state, ${ }^{116}$ and the principle of separation of powers (on the basis that a tribunal cannot judge a foreign state without usurping the role of the executive in the field of foreign relations). ${ }^{117}$ In addition, it is founded on the principle of independence of states and the protection of the property.

The risk related to the exercise by a state of its prerogative as public sovereign are of two distinct types: there is the risk that the state will invoke its immunity from jurisdiction and execution, and that it will refuse to appear before a foreign court arbitration tribunal. ${ }^{118}$ The exercise of immunity by states is in an obstacle to debt recovery and the exercise of commercial activity and as a result, individuals remain reluctant to contract with states. It also renders creditors defenseless and leaves them with no remedy. The question then, is how to overcome the barrier of immunity? The CCJA acknowledged the privilege granted to public

\footnotetext{
${ }^{108}$ Article 30, Debt Recovery and Enforcement Act.

109 Ibid.

110 Ibid.

${ }^{111}$ Ibid. CCJA Judgment No. 043/2005 of 7 July 2005.

${ }^{112}$ Judgment of 11 September 2000, High Court of Dschang.

${ }^{113}$ Article 49 OHADA Treaty.

${ }^{114}$ Article 50 (supra 111).

${ }^{115}$ Articles 42-43 OHADA Treaty.

${ }^{116}$ Article 2 (1), United Nations Charter, 1948.

117 Allen Demo (ed) (1998) Legal aspects of doing business with black Africa, Practicing Law Institute, New York, p52.

118 Allen (supra 120) 52.
} 


\section{International Journal of Social Sciences and Management Review}

companies, but required public companies to provide compensation to their creditors. ${ }^{119} \mathrm{At}$ the moment, the principle of compensation is the only way for a creditor seeking payment for its claim, but it is limited in the sense that only creditors whose claims are certain, liquid, and enforceable are entitled to compensation. ${ }^{120}$ Failing this, all possibility of compensation is excluded.

In spite of all efforts to the contrary, enforcement against the state has proven to be impossible. The SADC may consider adopting a similar approach by ensuring that creditors dealing with member states are compensated for any claim they might have against the state.

\subsection{Supranational organization}

According to Rasamond, supranationalism is 'the development of authoritative institutions of governance and network of policy-making activity above nation-states'. ${ }^{21}$ OHADA is a supranational organisation with the ability to take legally binding decisions and directly apply regional laws. It is important to take note here that the ability of OHADA to exercise supranational powers is based on the political commitment of the member states. OHADA only exercises powers conferred on it by the member states and cannot modify its powers. To a large extent, this factor has enhanced the successful functioning of OHADA. ${ }^{122}$ OHADA has witnessed the establishment of supranational institutions such as the Council of Ministers (council) and Common Court of Justice and Arbitration (CCJA), through which it exercises supranational powers. ${ }^{123}$ Laws adopted by the council are supreme and prevail over national laws, while decisions rendered by the CCJA are set as precedents for the national courts. ${ }^{124}$

\subsection{CONCLUSION}

Africa is not lagging in the development of commercial laws. This follows OHADA's moves towards the development of uniform commercial law rules, the fruits of which are visible in the member states. OHADA has paved the way for legal and judicial certainties in its member states by adopting uniform commercial laws that are directly applicable in the member states, and establishing supranational institutions for the implementation of the uniform laws. OHADA accepts the supremacy and direct effect of the UA's which create rights and obligations for member states. This paper examines the efforts of OHADA in developing uniform commercial laws in an attempt to determine whether it can serve as a model for the SADC. In so doing, the author submits that though OHADA has brought significant benefits to the member states, as discussed above, OHADA cannot serve as a model for the SADC because, inter alia, it does not reflect the language and legal particularities of the SADC region. On this basis, the paper submits that OHADA can only serve as a guide or roadmap for the SADC drafters.

\footnotetext{
${ }^{119}$ Article 32 (supra 108).

${ }^{120} \mathrm{Ibid}$, Art provides that a debt which is certain is one which is in existence and acknowledged by the creditor while a liquidated claim is one whose amount is ascertained in monetary terms.

${ }^{121}$ Rasamond Babatunde (2004) Theories of European integration, St Martin's Press, New York, p 204.

122 Babatunde Fagbayibo (2008) “A supranational African Union? Gazing into the crystal ball” De Jure, p 494.

${ }^{123}$ See chapter 4 of Leno ND's Thesis, 2014.

${ }^{124}$ Articles 10 and 20, OHADA Treaty.
} 


\section{International Journal of Social Sciences and Management Review}

As the SADC embarks on a journey of unifying its commercial laws and improving its current structure, efforts should be geared towards building on OHADA, because it offers instructive lessons. In order to complement the work of OHADA, it is highly desirable for the SADC drafters to consider the practice of other regional integration arrangements as well as some international commercial law instruments. As Mazrui aptly admonished 'Africa must stand ready to selectively borrow, adapt, and creatively formulate its strategies for planned development'. ${ }^{125}$ To this extent the EU experience and those of other regional and subregional initiatives in Africa are worth considering. The consideration of other initiatives and instruments is to draw and adapt useful lessons for the SADC in the development of a uniform commercial law structure in the region.

\section{REFERENCES}

Leno Doris (2014) "Development of a Commercial Law Structure in the SADC with reference to OHADA" LLD Thesis, University of Pretoria, Pretoria, 89-90

The Treaty of Southern African Development Community, Windhoek, 17 August 1992. The Treaty, after citing the objectives previously enunciated in the 'Southern African toward Economic Liberation - A Declaration by the Governments of Independent States of Southern Africa made at Lusaka, 1 April 1980' establishes the SADC

Leno Doris (2012) "Regionalism: Lessons the SADC can learn from OHADA" Journal of Contemporary Roman-Dutch Law, 75 (1), p256

Gbenga Bamodu (1994) "Transnational Law, Unification and Harmonisation of International Commercial Law in Africa" Journal of African Law, 38 (2), p130

Tabe-Tabe Simon (2009) "Company formation under the OHADA uniform Act on commercial companies and economic interest groups: Changes in the law hitherto applicable in the former west Cameroon" PhD Thesis, University of Yaoundé, Soa, 6

Carbonara EIger and Parisi Fissi (2007) "The Paradox of Legal Harmonisation" Public Choice, 34, p369

Fey Tigger (1999) "Labour Standards in Southern Africa in the Context of Globalisation: The need for a common Approach" Industrial Law Journal 20, p1481

SADC First International Conference convened in Maputo, Mozambique was premised on 'regional integration issues and SADC law'

<http://vi.unctad.org/files/mpzambique/uemsadcppt.doc> on 12 July 2017

The second conference was premised on 'mainstreaming regional integration through the harmonisation and modernisation of economic and business laws in southern Africa' <http://www.ohada.com/fichiers/newsletters/1039/program.pdf $>$ on 12 July 2017

${ }^{125}$ Mazrui Ali and Tidy Michael (1985) Nationalism and new states in Africa, Heinemann, London p48. 


\section{International Journal of Social Sciences and Management Review}

The Organisation for the Harmonisation of Business Law in Africa (OHADA) Treaty $17^{\mathrm{TH}}$ October 2008

Sands Philipe and Klein Pierre (2009) Bowette's law of international institutions, 5ed, Sweet \& Maxwell, London, 16.

Oppong Frippong (2009) "Relational issues of law and economic integration for Africa: Perspectives from Constitutional, Public and Private international Law" LLD Thesis, University of British Columbia, 13

Sackstein NO v. Proudfoot SA (Pty) Limited (2003), Appeal Court of South Africa. See Ward $v$ Smith and Others: In Re Gurr v Zambia Airways Corp Ltd (1998), Appeal Court of South Africa

Leno Doris (2013) "Development of a Uniform Insolvency Law in the SADC: Lessons from OHADA" Journal of African Law 57, p264

South African Insolvency Act No. 24 of 1936

Sarooshi Dan (2005) International Organisations and their exercise of Sovereign Powers, Oxford University Press, London, 66

Ebobrah Solomon and Nkhata Mwiza (2010) "Is the SADC Tribunal under judicial siege in Zimbabwe? Reflections on Etheredge $\mathrm{v}$ The Minister of State for National Security responsible for lands, land reform and resettlement and another" Comparative and International Law Journal of Southern Africa, XLIII, p82-92

Walsh Johnson and Ryan KIein (1977) "Harmonisation and Standardisation of Legal aspects of international trade" Australian Law Journal, 51, p608

Mason Rason (2008) "Cross-Border Insolvency Law: Where Private International Law and Insolvency Law meet" in Omar J (ed), International Insolvency Law: Themes and perspectives, Contd Ashgate Publishing Co, USA, 41

Penda Alain (2011) "The applicability of OHADA Treaty in Cameroon: The Way Forward" $<$ http://bit.ly/uJnZds> on 20 October 2011

Fontaine Marcel (2011) 'OHADA Uniform Act on Contract Law: Explanatory notes to the preliminary draft'-<http://bit.ly/tqkpxF> on 24 November 2011

Keba MarceI (2008) "OHADA: The Harmonisation of Business Law in Africa" 2008 <http://www.ohada.org/http://wwwohada.com> on 19 April 2017

World Bank 'Doing Business 2012/ Progress in Regulatory Reform expands Business opportunities across OHADA Member States' World Bank Doing Business Report 2012

Wehmeier Sydney and Ashby MichaeI (eds) (2000) Oxford Advanced Learner's 


\section{International Journal of Social Sciences and Management Review}

Volume: 03, Issue: 06 “November - December 2020”

ISSN 2582-0176

Dictionary of Current English, 6ed, Oxford University Press, Clarendon, 428

Paillusseau Jacque (2004) "Le Droit de l'OHADA: Un Droit trés Important et Original' Juridique Périodique, p1-2

Allan M,athews (2003) Regional Integration and Food Security in Developing Countries, Food and Agriculture Organisation of the United Nations, Rome, 7

Frilet Mordan (2007) "Implementing the Rule of Law in Sub-Saharan Africa: Appraisal of the OHADA Model after a Decade" International Business Law Journal, Volume (Issue) 8(3), p255

Dickerson Moore (2005) "Harmonising Business Laws in Africa: OHADA Calls the Tune" Columbia Journal of Transnational Law, 44, p21. 44

Chardon Miche (2017) <http://www.uihj.com/en/historica-pan-africa-seminar-injohannesburg-on-18-and-19-october-2007-1018332.html at 1> on 1 July 2017

Vermeulen Erik (2003) The Evolution of Legal Business forms Legal Business forms in Europe and the United States: Venture Capital, joint Venture and Partnership Structures, Kluwer Law International, the Hague, p173

Bourque Jacque, 'OHADA four years on: One business law for 16 African countries$\begin{array}{lllll}\text { international Trade } & \text { Centre } & \text { Issue } & 4, & \end{array}$ <http://www.tradeforum.org/news.fullstory.php/aid/497/> on 10 July 2017

Mariner Max and DM Ltd v Dumas Jean Raymond (2001), High Court of Kumba (unreported). Akiangan Fombin Sebastian v. Fotso Joseph and others (unreported) (2000), High Court of Kumba (unreported)

Leno Doris (2016) "The constitutional validity of the OHADA treaty in Cameroon" Global Journal of Management and Business Research, 1, p40-41

Tamko Victor (2004) 'Lectures on comparative law' 29 unpublished and on file with author.

Gopalan Sydney, 'From Cape Town to The Hague: Harmonisation has taken a wing' 10 <http://www.law.upenn.edu/journals/jil/jilp/articles/1-1_Gopalan_sandeep.pdf> on 22 June 2017

Mancuso SaIvadore (2010) 'Legal Integration in the SADC Region: A Methodological Approach' International Conference on the Trend of Economic Globalisation and Construction of the Rule of Law, Maputo, 4

Dugard John (2005) International law: A South African Perspective, Juta and Company Ltd, city, p47-78 


\section{International Journal of Social Sciences and Management Review}

Tumnde Martha (2009) "Cameroon offers a contextual approach to understanding the OHADA Treaty and Uniform Acts" in Dickerson Moore (ed), Unified Business Law in Africa: Common Law Perspective on OHADA, GMB Publishing Ltd, city, p47

Ekome Emmanuel (2002), "Landmark Development in Commercial Law Practice in Anglophone Cameroon: Conflicts beyond relief" Juris-Périodique, p86

Ruppel Cowell (2012) 'The case of Mike Campbell and the SADC Tribunal under Review' International Conference on Regional Integration and SADC Law, Maputo, 12

Popescu Dan, 'The relationship between national law, European law and international law in a multilevel governance system' 1 - http://www.federialism .chi/filles/FileDonload/918/Popescu_web.pdf on 2 July 2017

Oppong Frippong (2006) "Re-examining International Law: An examination of recent trends in the reception of International Law into National Legal Systems in Africa" Fordham International Law Journal, Issue 30, p307

Baba Mussa (2009) "Harmonisation of Business Laws in Africa - An insight into the laws, issues, problems and prospects" in Dickerson C (ed), Unified business law in Africa: Common law perspective on OHADA, GMB Publishing Ltd, United Kingdom, p3336

Martor Boris (2003) 'The OHADA legal harmonisation process: The benefits for Africa's development' Seminar on the applicability of OHADA treaty in Cameroon, Buea, 2003, p17-29

Koné M (2003) Le Nouveau Droit Commercial des Pays de la Zone OHADA: Comparaison avec le Droit Française, libraire générale et de jurisprudence, Paris, p157-158

Gutterman Brown (1997) Commercial laws of East Asia, Sweet \& Maxwell, London, p 29

Kruger Tiger (2008) "Regional organisations and their dispute settlement bodies" De Jure p306

Debt Recovery and Enforcement Act.

CCJA Judgment No. 043/2005 of 7 July 2005.

Judgment of 11 September 2000, High Court of Dschang.

Article 2 (1), United Nations Charter, 1948.

Allen Demo (ed) (1998) Legal Aspects of doing business with black Africa, Practicing Law Institute, New York, p52 


\section{International Journal of Social Sciences and Management Review}

Rasamond Babatunde (2004) Theories of European integration, St Martin's Press, New York, p 204

Babatunde Fagbayibo (2008) "A supranational African Union? Gazing into the crystal ball" De Jure, $\mathrm{p} 494$

Mazrui Ali and Tidy Michael (1985) Nationalism and new states in Africa, Heinemann, London $\mathrm{p} 48$ 